\title{
Sequestration of organic nitrogen in the sapropel from Mangrove Lake, Bermuda
}

\author{
Heike Knicker ${ }^{\text {a,* }}$, Patrick G. Hatcher ${ }^{b}$ \\ ${ }^{a}$ Lehrstuhl für Bodenkunde, Techmische Universität München, 85350 Freising, Germany \\ 'Department of Chemistry, The Ohio State University, Cohmbus, OH 43210, USA
}

\begin{abstract}
Humic isolates from different layers of an organic-matter-rich algal sapropel from Mangrove Lake, Bermuda, were subjected to solid-state ${ }^{15} \mathrm{~N}$ nuclear magnetic resonance (NMR) spectroscopy in order to reveal chemical structural interrelationships that allow delineation of diagenetic pathways. Amide-N, most likely from peptide-like material, was found to represent the main organic nitrogen form in all humic fractions at all depths of the sapropel. Amides were also identified in the residues from $6 \mathrm{M} \mathrm{HCl}$ hydrolysis of the alkaline insoluble extract (formerly called humin). These results indicate that some peptide-like material resists both alkaline and acid hydrolysis. We suggest that the chemical, and also the biological recalcitrance of peptide-like material, is related to encapsulation into the paraffinic network of algaenans. Being hydrophobic in nature, algaenan biomacromolecules may represent an effective means of protection against the attack of hydrophilic enzymes and aqueous extraction solutions.
\end{abstract}

Keywords: Solid-state ${ }^{15} \mathrm{~N}$ NMR; Sapropel diagenesis; Refractory organic nitrogen; Encapsulation

\section{Introduction}

An important source of organic matter in aquatic sediments is decomposing residues of aquatic plants such as planktonic and filamentous algae. Although a large fraction of this organic matter is decomposed and lost, a small proportion survives this mineralization process to become humic substances. Proteins and peptides, the major fraction of $\mathrm{N}$-containing molecules in living organisms, are expected to be part of the labile fraction which is quickly mineralized during early sediment diagenesis and can be reused for biological production. It has been suggested that nitrogen in marine systems becomes immobilized by condensation of carbohydrates and proteins via the Maillard reaction (Maillard, 1916;
Nissenbaum and Kaplan, 1972) to form melanoidins, the structure of which is still the subject of discussion (lkan, 1996). ${ }^{15} \mathrm{~N}$ NMR studies of artificial melanoidins showed, in addition to amide-nitrogen, signals in the chemical shift region assignable to pyridine- or pyrrole-analogs, indicating that nitrogen in melanoidins can occur in heteroaromatic-N (Benzing-Purdie and Ripmeester, 1983). It is thought that these melanoidins further condense to form fulvic acids, and eventually humin or proto-kerogen in marine sediments. This process of continued condensation is thought by some to lead to kerogen (Tissot and Welte, 1984). This pathway is supported by one of the few studies examining the formation of refractory nitrogen in marine sediments (Patience et al., 1992). Applying pyrolysis and X-ray photoelectron spectroscopy to sediment samples from the Peru upwelling area, they identified four different structures, namely pyridine, pyrrole, amides and, tentatively, quaternary nitrogen. Based on the finding that amide- $\mathrm{N}$ comprises at most $40 \%$ of the total nitrogen in the shallowest 
sample, it was suggested that the formation of heterocyclic aromatic nitrogen already started at or above the sediment/water interface. Recent solid-state ${ }^{15} \mathrm{~N}$ NMR spectroscopic studies on aged dissolved organic matter in the Gulf of Mexico (McCarthy et al., 1997) and preliminary results obtained from an investigation of modern and fossilized algal-derived sediments (Knicker et al., 1996), on the other hand, indicate that the formation of heteroaromatic nitrogen occurs after extended sediment maturation rather than during the early stages of diagenesis. The geochemical implications of this nitrogen transformation, however, are still not well understood.

A previously studied site for the examination of diagenetic processes in algal-derived sediments is Mangrove Lake, Bermuda, a small Holocene saline lake located approximately $100 \mathrm{~m}$ from the seashore (Hatcher et al., 1985). Based on the geology, radiocarbon dates and paleobotanical data, it was concluded that this lake formed around 10,000 years ago in a depression within the Pleistocene limestone bedrock (Land et al., 1967).

Being under investigation for a number of years, many aspects of the chemistry of the sapropel from Mangrove Lake have already been reported (Hatcher et al., 1980, 1982, 1985; Boudreau et al., 1992; Spiker and Hatcher, 1984). In a few studies, the diagenetic fate of the nitrogen (Hatcher et al., 1982; Boudreau et al., 1992; Knicker et al., 1996; Nguyen and Harvey, 1998) was considered, but a comprehensive examination of the organic nitrogen in light of the recent limited ${ }^{15} \mathrm{~N}$ NMR data has yet to be made. In the present study, we intend to provide a more complete understanding of diagenetic processes involved in refractory nitrogen formation, by subjecting humic fractions of the sapropel to solid-state ${ }^{13} \mathrm{C}$ and ${ }^{15} \mathrm{~N}$ NMR spectroscopy.

\section{Experimental}

\subsection{Sample material}

The organic-matter-rich sapropels from Mangrove Lake, Bermuda, when dried, are composed primarily of organic matter $(30-50 \%$ by weight), sea salts, calcium carbonate from gastropod and ostracod shells, and minor amounts of unclassified mineral matter. The anoxic, gelatinous, banded sapropel in a core, collected in 1971, extends to a depth of $14 \mathrm{~m}$. The lower interval between 11 and $14 \mathrm{~m}$ was deposited under freshwater lacustrine conditions and the upper interval, from $11 \mathrm{~m}$ up to the present sediment/water interface of the sapropel, formed under a brackish to saline environment, brought about by seawater penetration of the porous calcarenites encasing the basin as a result of sea level rise. For a detailed description of the sediments cored in 1971 (core labeled ML71-2-i or ML-71-2S-i, where $i$ is the sample reference number) the reader is referred to Hatcher et al. (1982). For some samples the humic fractions were not available or the obtained yields were to low for further analysis. Therefore sample material was used from an additional core that was taken in 1982. This core was collected with a $12.7 \mathrm{~cm}$ diameter piston core and labeled ML82C-i or ML82A-i. ${ }^{13} \mathrm{C}$ NMR spectroscopic comparison revealed that Mangrove Lake exhibits a comparable diagenetic history over a rather large area (data not shown).

\subsection{Sample preparation}

Dried samples were extracted successively with benzene/methanol $(1: 1 \mathrm{v} / \mathrm{v}), 0.1 \mathrm{M} \mathrm{HCl}$ and $0.5 \mathrm{M} \mathrm{NaOH}$ (under nitrogen). The base-extracted residues were then treated with a concentrated $\mathrm{HF} / \mathrm{HCl}$ solution (1:1) to remove most of the mineral matter and polysaccharidelike materials. This residual fraction is called RES and corresponds to a fraction formerly named humin (Hatcher et al., 1983a). The alkaline extract was passed through a Dowex $50 \mathrm{~W} \times 8\left(\mathrm{H}^{+}\right.$form $)$to become protonated. The acidified eluant was then centrifuged to separate the precipitate the acid insoluble fraction (AIF, formerly called humic acid) from the soluble part (ASF, formerly fulvic acid). Details of these fractionations is given by Hatcher et al. (1983a). The RES was further treated with refluxing $6 \mathrm{M} \mathrm{HCl}$ to hydrolyze labile biopolymers not removed by $\mathrm{HF} / \mathrm{HCl}$.

\subsection{Elemental composition}

The humic substances and freeze-dried sediment samples were analyzed for their C, H, N, O and S contents by a Carlo Erba Model 1106 Elemental Analyzer. Ash contents were determined as weight of residue from combustion at $750^{\circ} \mathrm{C}$ in air. Elemental data are reported on a moisture and ash-free basis.

\subsection{NMR spectroscopy}

The solid-state CPMAS ${ }^{13} \mathrm{C}$ NMR spectra of the dried humic material were obtained with a Brüker DSX $200(50.3 \mathrm{MHz})$, using zirconium rotors of $7 \mathrm{~mm}$ OD with KEL-F-caps that were spun at $6.8 \mathrm{kHz}$. A ramped ${ }^{1} \mathrm{H}$ pulse shaped from $100 \%$ down to $50 \%$ was used during contact time in order to circumvent spin modulation of Hartmann-Hahn conditions (Peersen et al., 1993). A contact time of $1 \mathrm{~ms}$ was used. The ${ }^{13} \mathrm{C}$ chemical shifts were calibrated to tetramethylsilane $(=0$ $\mathrm{ppm})$, using glycine as an external standard $(\mathrm{COOH}$ : $176.04 \mathrm{ppm})$. Between $2 \times 10^{4}$ and $10 \times 10^{4}$ scans were accumulated using a pulse delay of $400 \mathrm{~ms}$ (Fründ et al., 1989). Prior to Fourier transformation, a line broadening of 0 to $75 \mathrm{~Hz}$ was applied, depending on the sensitivity of the sample. 
The solid-state ${ }^{15} \mathrm{~N}$ NMR spectra were obtained on a Bruker MSL-300 spectrometer at a frequency of 30.4 $\mathrm{MHz}$, on a Chemagnetics CMC-300 spectrometer at a frequency of $30.2 \mathrm{MHz}$ and a Bruker DMX 400 at a frequency of $40.56 \mathrm{MHz}$ with a contact time of $0.7 \mathrm{~ms}$, a pulse delay of $200 \mathrm{~ms}$, and a spinning rate of 4.5, 4 and $5.5 \mathrm{kHz}$, respectively. The spectra were obtained after accumulation of approximately 500,000 to 1 million scans. The chemical shifts of all solid-state ${ }^{15} \mathrm{~N}$ NMR spectra were plotted referenced to external nitromethane $(=0 \mathrm{ppm})$, using glycine $(-347 \mathrm{ppm})$ as a surrogate standard.

\section{Results}

\subsection{Chemical composition of the bulk sapropel}

As demonstrated in earlier studies (Hatcher et al., 1982, 1983b) the elemental composition (Table 1), and the fairly constant atomic $\mathrm{H} / \mathrm{C}$ of 1.7 (typical for highly aliphatic material) throughout the sapropel from Mangrove Lake and their CPMAS ${ }^{13} \mathrm{C}$ NMR spectra (Hatcher et al., 1982) reflect the close relationship between degraded algal material and the sapropel. The main alteration in chemical composition occurring during sapropel maturation in the marine unit was found to be a considerable loss of carbohydrates and a simultaneous relative increase in paraffinic-C (Hatcher et al., 1982; 1983b). It was found that the major loss of $\mathrm{O} / \mathrm{N}$-alkyl-C occurs over a rather narrow interval at 2.5 to $4 \mathrm{~m}$. However, in the freshwater sapropel below $11 \mathrm{~m}$, the $\mathrm{O} /$ $\mathrm{C}$ ratios and the carbohydrate content were reported to increase to values similar to those of the surface sediments. Hatcher et al. (1983b) speculated that the environmental deposition during the freshwater interval was such that little diagenetic alteration occurred. Alternatively, it was suggested that this may be due to a change in the nature of source materials.

The solid-state ${ }^{15} \mathrm{~N}$ NMR spectra of the near surface layers of the marine sapropel of the cores ML71 and ML82 in Fig. 1 are surprisingly similar to those obtained from fresh algae, fungi and plants (Jakob et al., 1980; Knicker and Lüdemann, 1995; Knicker et al., 1996). They show their main signal at -257 ppm, typically found for amide nitrogen. Considering that the main source of this sapropel is algae and that proteinaceous materials constitute the bulk of algal biomass, this amide signal derives most likely from peptide-N. However, acetylated amino sugars, lactams, unsubstituted pyrroles, indoles and carbazoles, also show their chemical shift between -220 and -285 ppm and may contribute to the intensity of the signal at $-257 \mathrm{ppm}$ (Witanowski et al., 1993). The presence of significant amounts of unsubstituted pyrroles ( -200 to $-240 \mathrm{ppm})$ would shift the broad peak toward lower fields. Other signals, indicating the presence of proteinaceous material can be identified at $-346 \mathrm{ppm}$ in the region (free amino groups of amino acids or peptides and amino sugars) and the shoulder between -285 and $-320 \mathrm{ppm}$ in the chemical shift region of free amino groups in basic amino acids ( -285 to $-350 \mathrm{ppm})$.

Interestingly, the pattern for the solid-state ${ }^{15} \mathrm{~N}$ NMR spectra, does not change dramatically throughout the marine sapropel and the underlying freshwater unit. Although Hatcher et al. (1983b) found a decrease of

Table 1

Elemental data ( $\mathrm{mg} \mathrm{g}^{-1}$ dry sample) for the acid-washed bulk sapropel from Mangrove Lake, reported on a moisture- and ash-free basis

\begin{tabular}{|c|c|c|c|c|c|c|c|c|c|c|}
\hline Sample & $\begin{array}{l}\text { Depth } \\
(\mathrm{m})\end{array}$ & $\mathrm{C}$ & $\mathrm{N}$ & $\mathrm{H}$ & $\mathrm{O}$ & $\mathrm{S}$ & $\begin{array}{l}\text { Atomic } \\
\mathrm{H} / \mathrm{C}\end{array}$ & $\begin{array}{l}\text { Atomic } \\
\mathrm{O} / \mathrm{C}\end{array}$ & $\begin{array}{l}\text { Atomic } \\
\mathrm{C} / \mathrm{N}\end{array}$ & $\begin{array}{l}\text { Ash }+ \text { salts } \\
(\%)\end{array}$ \\
\hline \multicolumn{11}{|l|}{ Marine sapropel } \\
\hline ML71-2S-1 ${ }^{\mathrm{a}}$ & 0.24 & 484 & 46 & 69 & 438 & $\mathrm{NA}^{\mathrm{b}}$ & 1.7 & 0.7 & 12.3 & 49.9 \\
\hline ML71-2S-3 & 1.8 & 494 & 50 & 68 & 394 & NA & 1.7 & 0.6 & 11.5 & 48.1 \\
\hline ML71-2-33 & 2.3 & 504 & 38 & 70 & 313 & 54 & 1.7 & 0.5 & 15.5 & 43.5 \\
\hline ML71-2-32 & 2.7 & 504 & 49 & 71 & 374 & 52 & 1.7 & 0.6 & 12.0 & 47.3 \\
\hline ML71-2-30 & 3.6 & 552 & 53 & 73 & 291 & 55 & 1.6 & 0.4 & 12.2 & 36.0 \\
\hline ML71-2-27 & 5.1 & 510 & 43 & 71 & 301 & 56 & 1.7 & 0.4 & 13.8 & 23.3 \\
\hline ML71-2-24 & 7.0 & 560 & 47 & 79 & 277 & 60 & 1.7 & 0.4 & 13.9 & 50.0 \\
\hline ML71-2-20 & 9.7 & 520 & 40 & 73 & 294 & 59 & 1.7 & 0.4 & 15.2 & 15.7 \\
\hline $\begin{array}{l}\text { Freshwater sapropel } \\
\text { ML71-2-14 }\end{array}$ & 11.5 & 505 & 32 & 70 & 38.6 & 45 & 1.7 & 0.6 & 18.4 & 18.1 \\
\hline ML71-2-7 & 13.5 & 475 & 17 & 66 & 45.2 & 31 & 1.7 & 0.7 & 32.6 & 10.3 \\
\hline
\end{tabular}

a Data were not available for sample ML82-C-2. For comparison, the data from the corresponding sample obtained in 71 are presented.

b Not analyzed. 

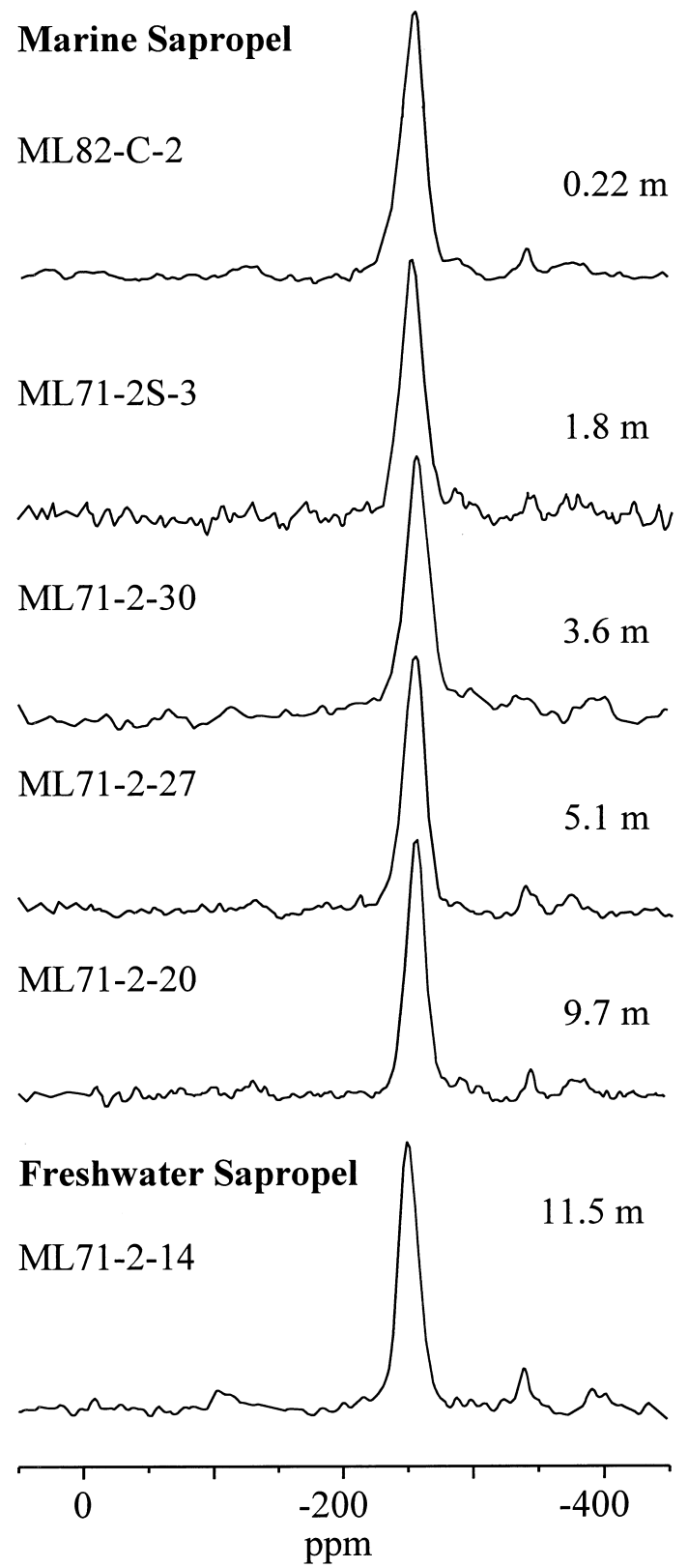

Fig. 1. Solid-state CPMAS ${ }^{15} \mathrm{~N}$ NMR spectra of the bulk sapropel from Mangrove Lake, Bermuda.

hydrolyzable amino acid content indicative of the degradation of proteinaceous material during sediment diagenesis, some amide structures seem to persist. No signals additional to those already observed in the solid-state ${ }^{15} \mathrm{~N}$ NMR spectra of the near surface layer of the marine unit can be identified. Obviously, no major change in nitrogen functionality has occurred during diagenesis of the Mangrove Lake sapropel. We conclude that little or no transformation of peptide- $\mathrm{N}$ to heteroaromatic- $\mathrm{N}$ has occurred during diagenesis, as revealed by the lack of considerable signal intensity in the chemical shift region assigned to imine- or pyridine- $\mathrm{N}$ between -25 and -90 ppm and in the region of pyrrole- $\mathrm{N}$ between -145 and $-220 \mathrm{ppm}$.

\subsection{Chemical composition of the acid-soluble fraction}

The acid-soluble fractions (ASF) of the marine sapropel from the intervals down to $3.8 \mathrm{~m}$ reflect similar elemental compositions and are composed of approximately $40 \%$ carbon, $6 \%$ hydrogen, 3 to $4 \%$ nitrogen and 34 to $41 \%$ oxygen (Table 2). Their atomic $\mathrm{O} / \mathrm{C}$ ratios range from 0.6 to 0.8 . Such values are typically found for highly oxygenated organic material, such as carbohydrates.

The presence of carbohydrates in these ASF-fractions is confirmed by the signal at 72 and $106 \mathrm{ppm}$ in their CPMAS ${ }^{13} \mathrm{C}$ NMR (Fig. 2). Note that a significant peak is observed at $175 \mathrm{ppm}$ for carboxyl/amide-C. In addition to amide- $\mathrm{C}$, contributions of carboxylic- $\mathrm{C}$ from uronic acid monomers, suggested to comprise a substantial amount of fulvic material (Hatcher et al., 1980), may add to this signal.

Compared to the solid-state CPMAS ${ }^{15} \mathrm{~N}$ NMR spectra of the whole sapropels, those of ASF show much higher intensity in the chemical shift region of free amino groups $(-346 \mathrm{ppm})$, most tentatively of amino acids and amino sugars (Fig. 2). The high abundance of free amino groups in these materials strongly leads to the conclusion that nitrogen in ASF is bound in short chain peptides and/or amino sugar units rather than in condensed macromolecules or higher molecular weight proteins. Interestingly, no signal of significance is observed in the chemical shift region of heteroaromatic- $\mathrm{N}$ or imine structures, revealing that in the sapropel from Mangrove Lake, such structures have no major impact on the chemical structure of its ASF nitrogen.

It is interesting to note that the patterns of the solidstate CPMAS ${ }^{13} \mathrm{C}$ and ${ }^{15} \mathrm{~N}$ NMR spectra of the ASFfractions from different sapropel depths are similar even though significant changes in chemical composition were observed in the whole sapropel of the same intervals (Hatcher et al., 1982). On the other hand, alterations are observed in the yields of ASF (Table 2). Data obtained for samples not analyzed by solid-state CPMAS ${ }^{15} \mathrm{~N}$ NMR are included into Table 2 for comparison. They decrease with increasing sediment depth. The higher yields in the upper layers of the sapropel can be explained by a greater abundance of carbohydratelike and labile proteinaceous substances. In the lower layers, at depths greater than $2.5 \mathrm{~m}$, the amount of carbohydrate-like and extractable proteinaceous substances were found to be lower in the total sapropel (Hatcher et al., 1982). The yields of ASF are correspondingly lower. This parallel trend between yield of ASF and extractable 
Table 2

Elemental composition ( $\mathrm{mg} \mathrm{g}^{-1}$ dry sample) of the acid soluble fractions (ASF) of the sapropel from Mangrove Lake, Bermuda, reported on a dry sediment basis and their yields as \% carbon (C) of total organic carbon (TOC) of the bulk sapropel

\begin{tabular}{lllllllllr}
\hline Sample & $\begin{array}{l}\text { Depth } \\
(\mathrm{m})\end{array}$ & $\begin{array}{l}\text { Yield \% C } \\
\text { of TOC }\end{array}$ & $\mathrm{C}$ & $\mathrm{N}$ & $\mathrm{H}$ & $\mathrm{O}$ & $\begin{array}{l}\text { Atomic } \\
\mathrm{H} / \mathrm{C}\end{array}$ & $\begin{array}{l}\text { Atomic } \\
\mathrm{O} / \mathrm{C}\end{array}$ & $\begin{array}{l}\text { Atomic } \\
\mathrm{C} / \mathrm{N}\end{array}$ \\
\hline ML82-A-2 & 0.08 & 5.4 & 403 & 41 & 58 & 370 & 1.7 & 0.7 & 11.5 \\
ML82C-4 & 0.52 & 5.2 & 361 & 26 & 50 & 380 & 1.7 & 0.8 & 16.2 \\
ML82C-10 & 1.8 & 1.1 & 389 & 42 & 51 & 343 & 1.6 & 0.7 & 9.8 \\
ML82C-16 & 3.0 & 2.2 & 433 & 31 & 56 & 352 & 1.6 & 0.6 & 16.3 \\
ML82C-20 & 3.8 & 1.1 & 413 & 34 & 69 & 409 & 2.0 & 0.7 & 14.2 \\
\hline
\end{tabular}

\section{CPMAS 13}
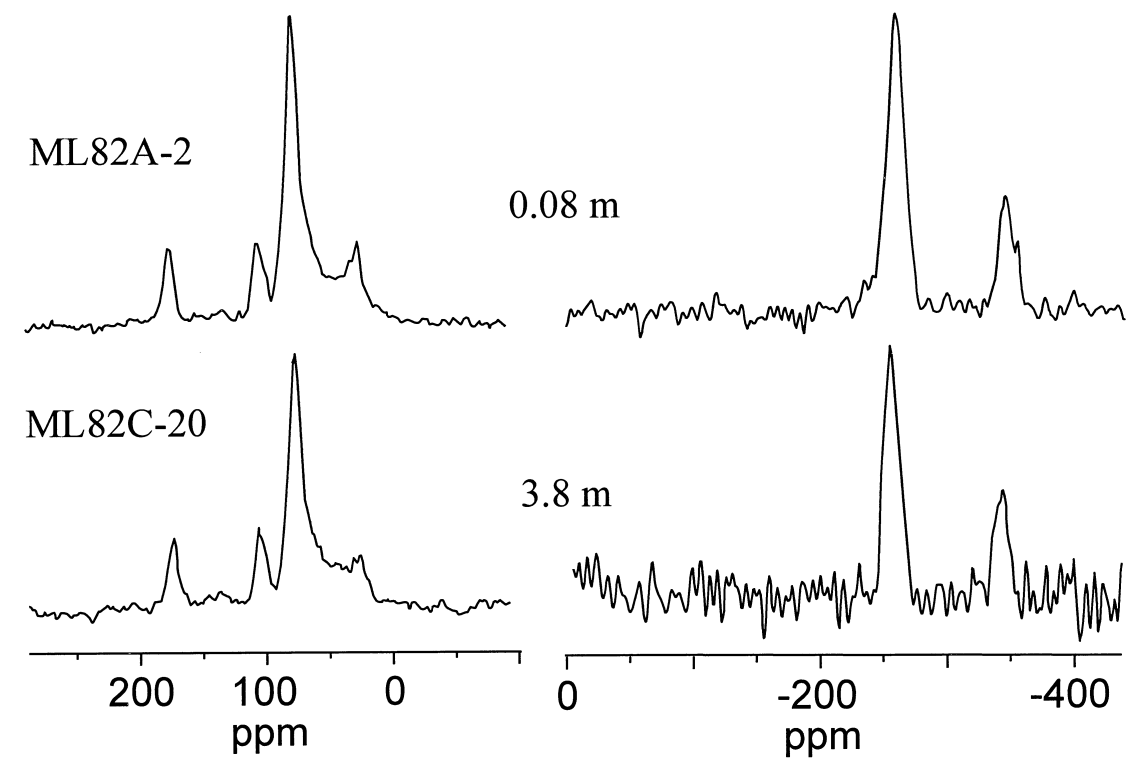

Fig. 2. Solid-state CPMAS ${ }^{13} \mathrm{C}$ and ${ }^{15} \mathrm{~N}$ NMR spectra of acid soluble fractions (ASF) of the algal sapropel from Mangrove Lake.

carbohydrate and protein content of the sapropel supports biopolymer degradation models in which it is assumed that the acid-soluble fraction (formerly, fulvic acids) are merely degradation products of labile biopolymers (Hedges, 1988).

\subsection{Chemical composition of the acid-insoluble fractions ( $A I F)$}

The acid-insoluble fractions (AIF) from the marine sapropel contain about $40 \%$ carbon, $6 \%$ hydrogen and 4 to $6 \%$ nitrogen (Table 3 ). Values for oxygen range from highs of $38 \%$ in upper layers of the marine sapropel to $30 \%$ in the lower layers. However, in the AIF of the freshwater sapropel the oxygen content exceeds that of the upper marine layers $(44.6 \%)$. This observation supports the assumption that its biogenic precursors contained oxygen-rich material. This is supported by the corresponding CPMAS ${ }^{13} \mathrm{C}$ NMR spectrum in Fig. 3. For the spectra above $3.8 \mathrm{~m}$ a relative loss of polysaccharides (peaks at 72 and $106 \mathrm{ppm}$ ) and a relative increase of paraffinic carbons (30 ppm) is observed. As depth increases to $3.8 \mathrm{~m}$, the CPMAS ${ }^{13} \mathrm{C}$ NMR spectrum of the AIF becomes more similar to spectra obtained from the whole sapropel (Hatcher et al., 1983b). Note that this spectrum still shows a signal between 45 and 60 ppm, typical for $\mathrm{N}$-substituted aliphatic carbons, and a peak at $175 \mathrm{ppm}$ for carboxyl/amide groups. The presence of peptides is confirmed by the corresponding CPMAS ${ }^{15} \mathrm{~N}$ NMR spectrum that has a strong similarity with that obtained for a sample from the surface layer (Fig. 3). This amide-N most likely accounts for the protein content previously determined by base extraction followed with a colorimetric test (Hatcher et al., 
1982). The protein content decreases from approximately $5.5 \%$ of the total organic matter to $1.3 \%$ in the freshwater gel (Hatcher et al., 1982). A comparable trend is observed for the content of AIF carbon with $19 \%$ of the total carbon in the uppermost layer to $1.1 \%$ in the freshwater gel (Table 3).

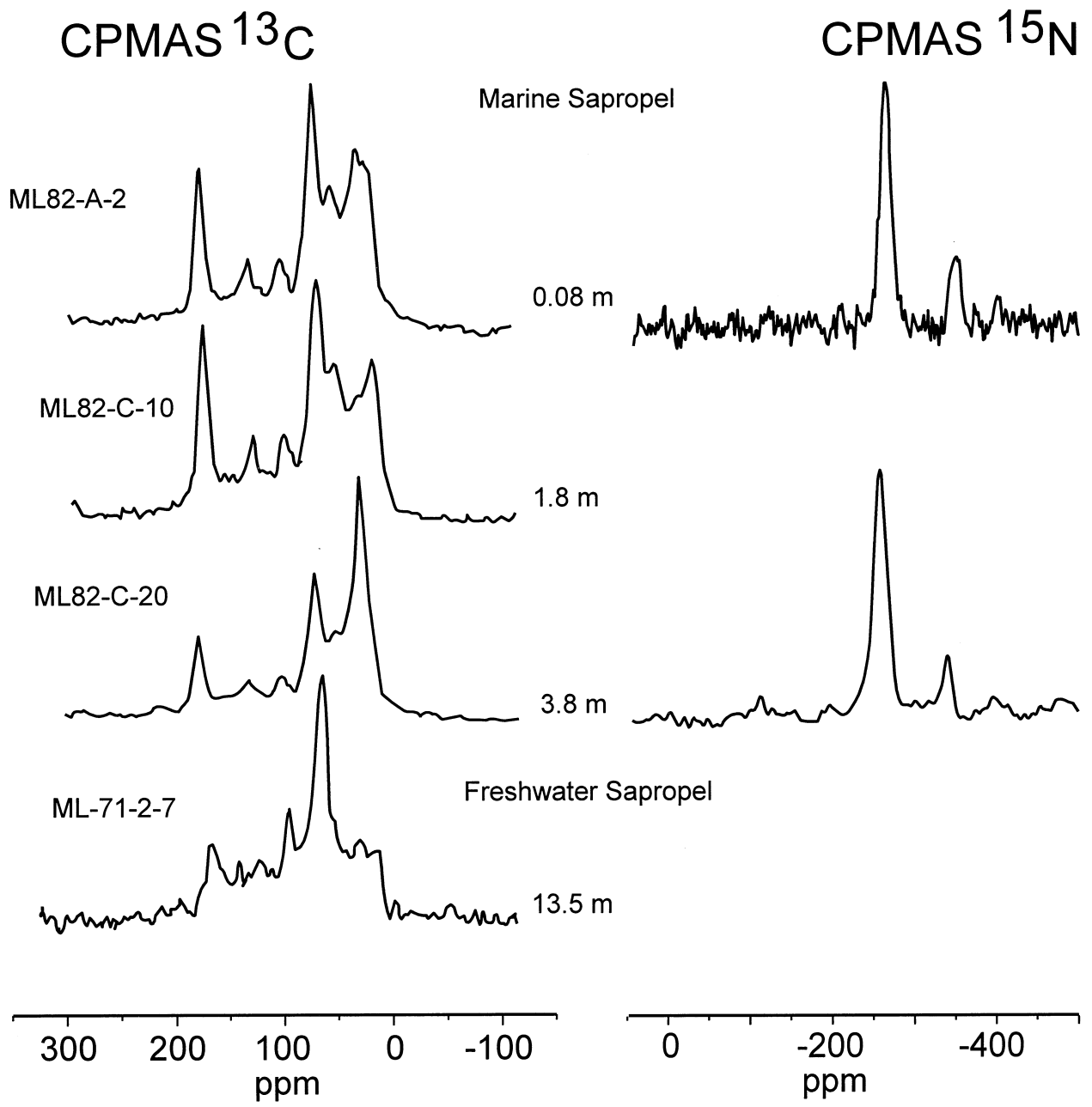

Fig. 3. Solid-state CPMAS ${ }^{13} \mathrm{C}$ and ${ }^{15} \mathrm{~N}$ NMR spectra of acid insoluble fractions (AIF) of the sapropel from Mangrove Lake.

Table 3

Elemental composition ( $\mathrm{mg} \mathrm{g}^{-1}$ dry sample) of the acid insoluble fraction (AIF) from Mangrove Lake, Bermuda, reported on a dry sediment basis and their yields as \% carbon (C) to total organic carbon (TOC) of the bulk sapropel

\begin{tabular}{|c|c|c|c|c|c|c|c|c|c|}
\hline Sample & $\begin{array}{l}\text { Depth } \\
(\mathrm{m})\end{array}$ & $\begin{array}{l}\text { Yield } \% \mathrm{C} \\
\text { of TOC }\end{array}$ & $\mathrm{C}$ & $\mathrm{N}$ & $\mathrm{H}$ & $\mathrm{O}$ & $\begin{array}{l}\text { Atomic } \\
\mathrm{H} / \mathrm{C}\end{array}$ & $\begin{array}{l}\text { Atomic } \\
\mathrm{O} / \mathrm{C}\end{array}$ & $\begin{array}{l}\text { Atomic } \\
\mathrm{C} / \mathrm{N}\end{array}$ \\
\hline \multicolumn{10}{|l|}{ Marine sapropel } \\
\hline ML82-A-2 & 0.08 & 19 & 454 & 63 & 60 & 296 & 1.6 & 0.5 & 8.4 \\
\hline ML82-C-4 & 0.52 & 13 & 450 & 57 & 63 & 382 & 1.7 & 0.6 & 9.2 \\
\hline ML82-C-10 & 1.8 & 8.4 & 447 & 60 & 53 & 324 & 1.4 & 0.5 & 8.7 \\
\hline ML82-C-16 & 3.0 & 0.7 & 456 & 54 & 61 & 317 & 1.6 & 0.5 & 9.9 \\
\hline ML82C-20 & 3.8 & 2.5 & 508 & 42 & 65 & 302 & 1.6 & 0.5 & 12.1 \\
\hline $\begin{array}{l}\text { Freshwater Sapropel } \\
\text { ML71-2-7 }\end{array}$ & 13.5 & 1.1 & 433 & 18 & 58 & 446 & 1.6 & 0.8 & 28.1 \\
\hline
\end{tabular}


3.4. Chemical composition of the residue after alkaline extraction (RES)

As revealed in Table 4, the carbon from the residue after alkaline extraction (RES) increases from $17 \%$ of TOC in the near surface layer to values of about $70 \%$ at approximately $4 \mathrm{~m}$ depth and remains in this range to a depth of $11 \mathrm{~m}$. According to their atomic $\mathrm{H} / \mathrm{C}$ ratio of 1.5 and atomic $\mathrm{O} / \mathrm{C}$ ratio of 0.4 a highly paraffinic structure is assumed. As demonstrated earlier, their solid-state CPMAS ${ }^{13} \mathrm{C}$ NMR spectra reveal minor alteration in chemical composition with increasing depth and that they are primarily composed of paraffinic carbons with few aromatic carbons, moderate levels of carboxyl/ amide carbons and aliphatic $\mathrm{C}-\mathrm{O}$ carbons (Hatcher et al., 1982; 1983b).

The nitrogen contents of the RESs of the sapropel range between 3 and 5\% (Table 4). As shown in Fig. 4, this nitrogen, compared to that of the whole sapropel, exists mainly in amide functional groups and to a lower extent, in free amino groups of aliphatic chains. This indicates that most of the nitrogen is bound in peptidelike structures.

Heteroaromatic nitrogen is not detected in any of the spectra, supporting the contention that the transformation of biogenic amides to diagenetically formed pyrroleand pyridine-type melanoidins is unlikely. Aside from this, no signal is found that indicates the formation of imine structures as suggested by a model published by Nguyen and Harvey (1998). The dominance of nitrogen assignable to peptides, demonstrates that extraction with alkali did not efficiently remove such components. Alternatively, hydrolysis by refluxing in $6 \mathrm{M} \mathrm{HCl}$, a fairly rigorous hydrolysis, is generally believed to remove all proteinaceous material. Subjecting the RESs of the sapropel to this treatment (RES-HCl) induces a loss of nitrogen and an increase in carbon content (Table 4), indicating the removal of some proteinaceous material. Further changes induced by $\mathrm{HCl}$ hydrolysis include a change in $\mathrm{O} / \mathrm{C}$ ratios, demonstrating a loss of carbohydrates. This is confirmed by the decrease of signal intensity in the O-alkyl region of their ${ }^{13} \mathrm{C}$ NMR spectra (data not shown). An increase in sulfur content is also observed (Table 4), suggesting that sulfur is an integral part of the refractory organic fraction in such sediments or that it represents pyrite.

However, as demonstrated by the peak around -260 ppm in the CPMAS ${ }^{15} \mathrm{~N}$ NMR spectrum (Fig. 4) of the $\mathrm{RES}-\mathrm{HCl}$ fraction from the marine unit at $3.6 \mathrm{~m}$ depth and as previously shown in that of the freshwater unit from $11.5 \mathrm{~m}$ depth (Knicker and Hatcher, 1997), at least some of the nitrogen of this fractions occurs as amide, protected from the intense chemical hydrolysis. Thus, both base extraction and acid hydrolysis failed to considerably alter the spectral signature of the organic nitrogen fraction in these samples.

To reveal the nature of amide- $\mathrm{N}$ in the hydrolysis residues of RES, those of the marine unit at $3.6 \mathrm{~m}$ and the freshwater unit at $11.5 \mathrm{~m}$ were previously subjected to tetramethylammonium hydroxide (TMAH) thermochemolysis (Knicker and Hatcher, 1997; Knicker et al., 2001). The corresponding chromatograms showed peaks of amino-acid-derived products that were also identified after TMAH/thermochemolysis of commercially available peptides with known structures, bovine albumin and the protein-rich algae Spirulina (Knicker et al., 2001). These results support the assumption that at least some of the amide- $\mathrm{N}$ in the CPMAS ${ }^{15} \mathrm{~N}$ NMR spectra of the hydrolysis residues originates from peptide-like structures that have survived: (1) diagenetic alteration in the sapropel; and (2) treatment with dilute alkali followed by $6 \mathrm{M} \mathrm{HCl}$.

Table 4

Elemental data ( $\mathrm{mg} \mathrm{g}^{-1}$ dry sample) for the residues after alkaline extraction of the Mangrove Lake sapropel reported on a dry sediment basis and their yields as \% carbon (C) to total organic carbon (TOC) of the bulk sapropel

\begin{tabular}{|c|c|c|c|c|c|c|c|c|c|c|}
\hline Sample & $\begin{array}{l}\text { Depth } \\
\text { (m) }\end{array}$ & $\begin{array}{l}\text { Yield } \% \mathrm{C} \\
\text { of TOC }\end{array}$ & $\mathrm{C}$ & $\mathrm{N}$ & $\mathrm{H}$ & $\mathrm{O}$ & $\mathrm{S}$ & $\begin{array}{l}\text { Atomic } \\
\mathrm{H} / \mathrm{C}\end{array}$ & $\begin{array}{l}\text { Atomic } \\
\mathrm{O} / \mathrm{C}\end{array}$ & $\begin{array}{l}\text { Atomic } \\
\mathrm{C} / \mathrm{N}\end{array}$ \\
\hline \multicolumn{11}{|c|}{ Marine sapropel } \\
\hline ML71-2S- $1^{\mathrm{a}}$ & 0.24 & 17 & 571 & 34 & 71 & 263 & 61 & 1.5 & 0.4 & 19.6 \\
\hline ML71-2-30 & 3.6 & 69 & 576 & 37 & 73 & 266 & 48 & 1.5 & 0.4 & 18.2 \\
\hline ML71-2-27b & 5.1 & 61 & 542 & 44 & 69 & 285 & 60 & 1.5 & 0.4 & 14.4 \\
\hline ML71-2-27c & 5.1 & n.d. & 626 & 29 & 80 & 182 & 80 & 1.5 & 0.2 & 25.2 \\
\hline ML71-2-20 & 9.7 & 67 & 544 & 49 & 70 & 277 & 60 & 1.5 & 0.4 & 13.0 \\
\hline \multicolumn{11}{|c|}{ Freshwater Sapropel } \\
\hline ML71-2-14 & 11.5 & 61 & 530 & 31 & 63 & 330 & 46 & 1.4 & 0.5 & 19.9 \\
\hline ML71-2-14 & 11.5 & 44 & 614 & 30 & 76 & 212 & 68 & 1.5 & 0.3 & 23.9 \\
\hline
\end{tabular}

a Data were not available for sample ML82-C-2. For comparison, the data from the corresponding sample obtained in 1971 are presented.

b Data were not available for the hydrolysis residue. For comparison, the data of the hydrolysis residue of sample ML71-2-27 are given.

${ }^{\mathrm{c}}$ a: RES hydrolyzed by reflux with $6 \mathrm{M} \mathrm{HCl}$. 


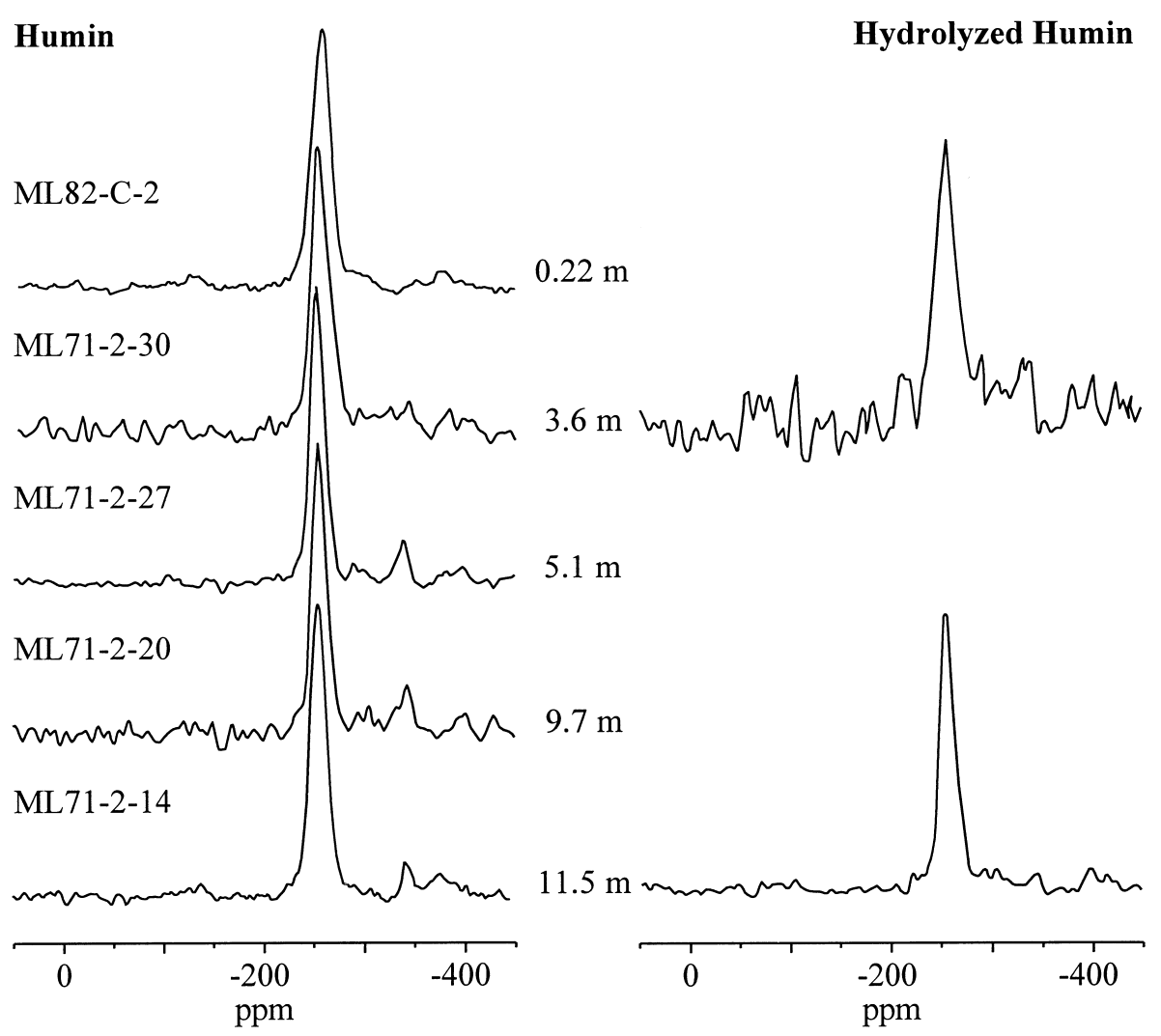

Fig. 4. Solid-state CPMAS ${ }^{15} \mathrm{~N}$ NMR spectra of the residues after alkaline extraction (RES) of the sapropel and their HCl-hydrolysis residues.

\section{Summary and discussion}

The sapropel from Mangrove Lake, Bermuda, represents a unique sequence of organic-matter-rich deposits that provided a wealth of information concerning processes involved in the maturation of organic matter in a subaquatic environment with mostly algal input. Previous examination of the chemical composition of the bulk sapropel with depth, reflected diagenetic alterations which are expressed as an increase of paraffinic structures with a simultaneous decrease of carbohydrate (Hatcher et al., 1982). This decrease in carbohydrates was also revealed in the chemical composition of the acid insoluble fraction that with increasing sapropel depths was shown to become more aliphatic in nature and begin to structurally resemble the insoluble residue after alkaline extraction (formerly humin) (Hatcher et al., 1983b). A relatively constant chemical composition that is mostly carbohydrates is observed for the acid insoluble fraction (formerly humic acid). The data presented in this study, however, showed that the nitrogen, both of the acid insoluble and the acid soluble fractions (formerly fulvic acid) in the considered depth range, is mainly bound in amide functional groups. Indication for the formation of nitrogen containing aromatic com- pounds with increasing organic matter maturation were not obtained. No signals were found that could support the formation of imine structures via condensation of carbohydrates and $\mathrm{N}$ of proteinaceous material (Nguyen and Harvey, 1998). Further, the consistency in nitrogen composition gives strong evidence that the common concepts suggesting that organic matter maturation in algal deposits occurs via recondensation into heteroaromatic N-components of small molecules (Nissenbaum and Kaplan, 1972) do not represent an important pathway in the sapropel of Mangrove Lake.

The yields of extractable AIF and ASF as a function of sapropel depths, show important trends that imply an alternative degradative pathway for their production. As shown earlier, with increasing depths, the yield of both AIF and ASF diminishes to minor levels. However, those yields correlate directly with the presence of extractable organic materials in the sapropel (Hatcher et al., 1982). Thus, in the upper layers where labile substances abound, AIF and ASF constitute a significant fraction of the total carbon and nitrogen. As degradation proceeds as a function of depth, the labile components of the sapropel have been reduced to the point that extraction with $0.5 \mathrm{M} \mathrm{NaOH}$ yields few components that can contribute to AIF and ASF, and the dominant com- 
ponents of the AIF are those that resemble the insoluble paraffinic structures that constitute the RES. These paraffinic components are probably present in low abundance at all levels of the sapropel but only become important contributors at depth where the carbohydrate-like materials no longer are incorporated into the AIF isolate.

With respect to the carbon functionality, the acid and alkaline insoluble, highly paraffinic fraction of the marine and freshwater sapropel was reported to be structurally similar (Spiker and Hatcher, 1984). As is shown here, this is also true for their nitrogen composition. Consequently, different lacustrine environments, which undoubtedly supported different algal populations, produced refractory fractions of sapropel that are, according to their ${ }^{13} \mathrm{C}$ and ${ }^{15} \mathrm{~N}$ NMR spectra, remarkably similar in chemical structures. Such refractory alkaline insoluble material (humin) was isolated from all intervals in the sapropel including the uppermost layers. This suggests that this material is either produced rapidly from degradation residues of dead algal cells or that it is an original component of algae. A strong correlation was observed between the stable carbon isotopic composition of RES and shells at equivalent intervals (Spiker and Hatcher, 1984). This implies that the RES is primary and an original component of algae. One could argue, however, that if RES were a diagenetic product it would retain its isotopic composition and the correlation would not be impaired. On the other hand, previous studies of different algae, have shown that an insoluble, resistant highly aliphatic biopolymer, with a CPMAS ${ }^{13} \mathrm{C}$ NMR spectrum similar to that of RES (humin) in the sapropel from Mangrove Lake (Hatcher et al., 1985), constitutes a significant fraction of the cell wall of these algae (Berkaloff et al., 1983; Blokker et al., 1998; Derenne et al., 1992; Kadouri et al., 1988; Largeau et al., 1984). Thus, the strong correlation between the loss of labile components, such as hydrolyzable proteins, and carbohydrates and the enrichment of highly paraffinic RES in the samples studied here, is most easily and logically explained by selective preservation of refractory RES (humin), having high contributions from algaenan.

As aforementioned the organic nitrogen fraction of all humic fractions of the marine and of the freshwater sapropel appears to be mainly composed of proteinaceous material. Such material, on the other hand, is generally expected to be easily digested by microorganisms. Its survival during sapropel maturation, thus, begs for an explanation for their protection.

One discussed protection mechanism for the longterm survival of generally believed labile compounds (Hedges and Keil, 1995) involves the $\mathrm{O}_{2}$-deficiency observed in sediments deposited under high productivity environments and known to decrease microbial activity (Emerson and Hedges, 1988; Henrichs, 1992). However, laboratory and field studies, determining the relative mineralization rates of bulk organic matter, or specific biochemical components under oxic vs. anoxic conditions, showed little or no effect of $\mathrm{O}_{2}$ availability on degradation rates (Hedges and Cowie, 1991; Lee, 1992). Exceptions were found for oxygen-poor, hydrolysisresistant material such as lignin (Kirk, 1984), lipids (Harvey et al., 1986) and photosynthetic pigments (Sun et al., 1993).

Another explanation for the preservation of labile organic molecules, such as peptides, may be their interactions with the mineral phase. Adsorption onto clay minerals (Ensminger and Gieseking, 1942; Marshmann and Marshall, 1981; Rosenfeld, 1979; Wang and Lee, 1993) presumably decreases enzyme activity due to formation of sterically protected substrate/mineral chemisorptive interactions. It was proposed that labile organic matter is entrapped in mesopores $(<10 \mathrm{~nm})$ which are too small for enzyme access (Mayer, 1994a,b). These mechanisms may be important in sediments with high mineral matter contents. However, it cannot explain the observed preservation of proteinaceous organic nitrogen in the sapropel of Mangrove Lake, where the clay and/ or mineral content is low $(<10 \mathrm{w} / \mathrm{w})$.

The long-term survival of labile proteins in Mangrove Lake sapropel may result from their interaction with refractory organic material in the sediment which offers protection from degradation. Considering the high sulfur content of the sapropel and its resistance against HCl-hydrolysis, sulfur-bridging, as a kind of natural vulcanization, may be involved in the stabilization of $\mathrm{N}$ containing aliphatic chains.

A further possible explanation represents protection by entrapment of the originally labile components into material that resists microbiological degradation. Keeping in mind that the major fraction of nitrogen in the older layers of the sapropel is part of RES, and that this RES exhibits a large amount of hydrophobic aliphatic material, most probably from algaenan, the survival of these proteinaceous materials may occur through protection by the refractory algaenan. Evidence for this assumption was obtained from the CPMAS ${ }^{15} \mathrm{~N}$ NMR spectra that were previously acquired from the algaenan of a mixed ${ }^{15} \mathrm{~N}$-enriched algal culture (Knicker et al., 1996) and the algaenan of ${ }^{15} \mathrm{~N}$-enriched Scenedesmus communis (formerly Scendesmus quadricauda) (Derenne et al., 1993). These spectra show that in those samples, nitrogen occurs mainly in amide functional groups. This strongly indicates that the resistance of peptide-like material to chemical degradation can occur independently from the presence of clay or minerals.

Based on recent and previous preliminary results obtained for the nitrogen fraction of the Sapropel from Mangrove Lake, an alternative pathway was introduced (Knicker and Hatcher, 1997, 2001), summarized in Fig. 5. As depicted in this figure, the amides may derive from proteinaceous material connected with the recalcitrant 


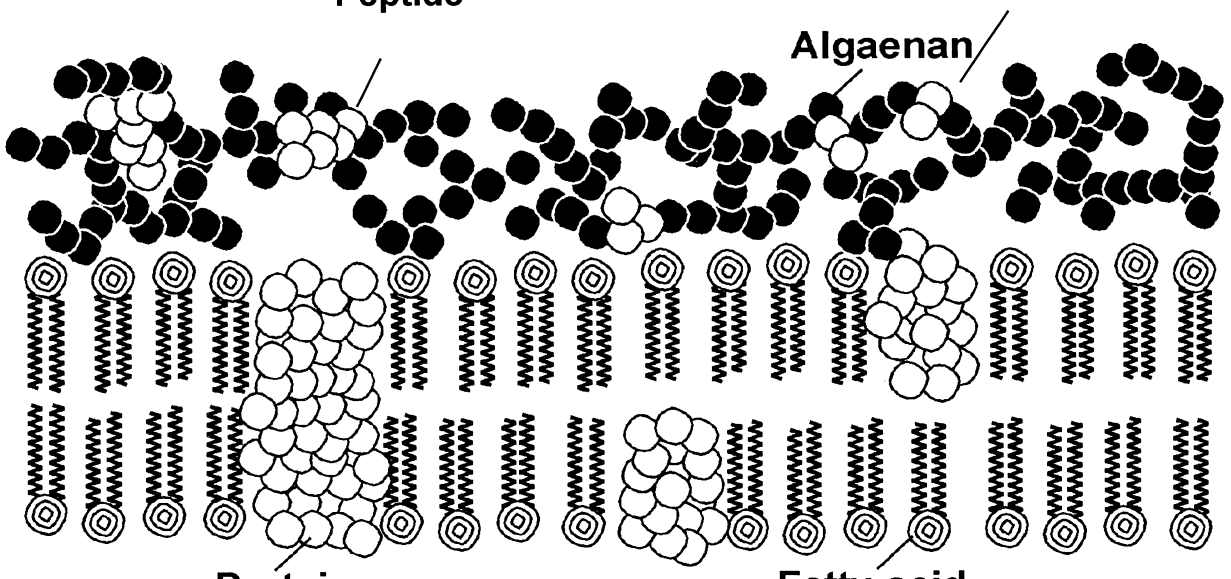

Protein
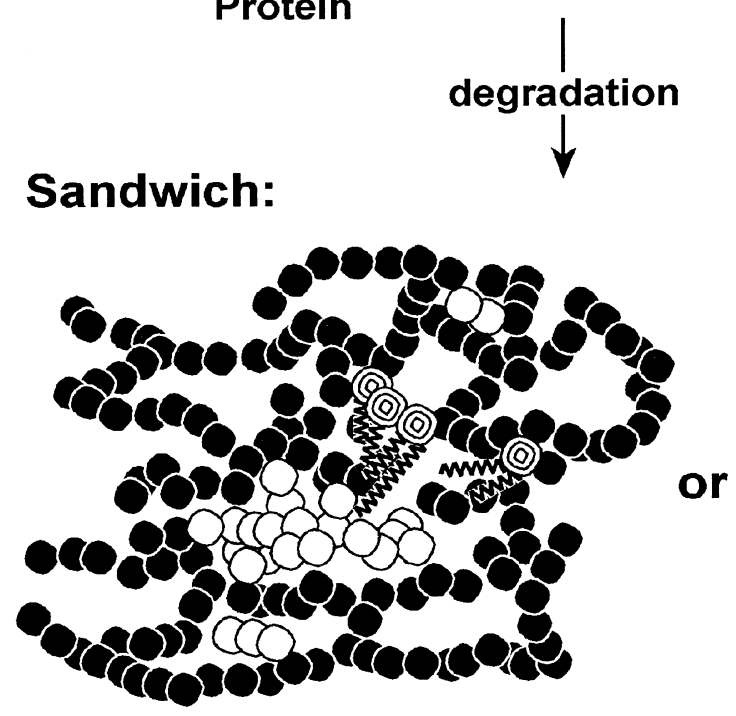

\section{Junction:}

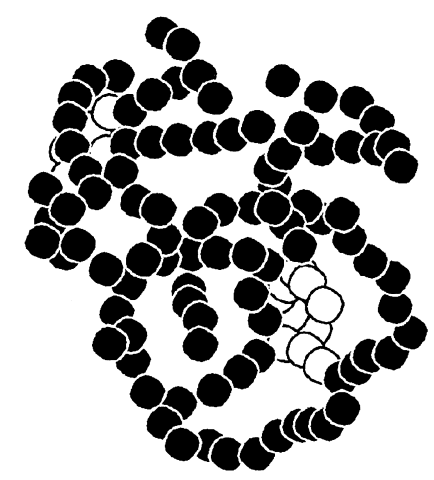

Fig. 5. Conceptual scheme for the preservation of proteinaceous material in algal-derived organic remains.

algal biopolymers that during degradation become surrounded by those structures and thus encapsulated in their network while other, more accessible compounds, are digested by microorganisms (Junction Pathway). It is also likely that the protected proteins comprise parts of the algal cell walls and that they become sandwiched between algaenan layers during diagenesis (Sandwich Pathway). Due to the hydrophobic nature of the algaenan, hydrophilic enzymes will not have access to certain key structures of the proteinaceous material which, therefore, resist enzymatic degradation. Only conditions that alter the steric configuration of the paraffinic macromolecule may liberate the proteinaceous compounds such that they become accessible for microbial activity and chemical extraction. Encapsulation of labile protein into refractory organic matter may not be restricted to algal material but can also be associated with other hydrophobic or protective biopolymers such as cell wall components of bacteria. One possible structure represents the bacterial peptidoglycan skeleton with its functional groups designed to prevent enzymatic attack. Thus, at the present stage of research, detritus of bacterial biomass cannot be excluded as a possible additional source of refractory structures involved in the accumulation of protected amides in algal derived sapropels.

$$
\text { Associate Editor - C. Largeau }
$$

\section{References}

Benzing-Purdie, L., Ripmeester, J.A., 1983. Melamcidius and soil organic matter: evidence of strong simularities revealed by ${ }^{13} \mathrm{C}$ CP-MAS NMR. Soil Science Society of America Journal 47, 56-61. 
Berkaloff, C., Casadevall, E., Largeau, C., Metzger, P., Peracca, S., Virlet, J., 1983. The resistant polymer of the walls of the hyrocarbon-rich algae Botryococcus braunii. Phytochemistry 22, 389-397.

Blokker, P., Schouten, S., van den Ende, H., de Leeuw, J.W., Hatcher, P.G., Sinnighe-Damsté, J.S., 1998. Chemical structure of algaenans from the fresh water algae Tetraedon minimum, Scenedesmus communis and Pediastrum boryanum. Organic Geochemistry 29, 1453-1468.

Boudreau, B.P., Canfield, D.E., Mucci, A., 1992. Early diagenesis in a marine sapropel, Mangrove Lake, Bermuda. Limnology and Oceanography 37, 1738-1753.

Derenne, S., Largeau, C., Hatcher, P.G., 1992. Structure of Chlorella fusca algaenan: relationships with ultralaminae in lacustrine kerogens; species - and environment-dependent variations in the composition of fossil ultralaminae. Organic Geochemistry 18, 417-422.

Derenne, S., Largeau, C., Taulelle, F., 1993. Occurrence of nonhydrolysable amides in the macromolecular constituent of Scenedesmus quadricauda cell wall as revealed by ${ }^{15} \mathrm{~N}$ NMR: origin of $n$-alkylnitriles in pyrolysates of ultralaminae-containing kerogens. Geochemica et Comochimica Acta 57, 851-857.

Emerson, S., Hedges, J.I., 1988. Processes controlling the organic carbon content of open ocean sediments. Paleooceanography 3, 621-634.

Ensminger, L.E., Gieseking, J.E., 1942. Resistance of clayadsorbed proteins to proteolytic hydrolysis. Soil Science 50, 205-209.

Fründ, R., Lüdemann, H.-D., González-Vila, F.J., Almendros, G., del Río, J.C., Martín, F., 1989. ${ }^{13}$ C-NMR spectroscopy of lignins and lignocellulosic materials: structural differences between humic fractions from different soil types as determined by FT-IR and ${ }^{13} \mathrm{C}$-NMR studies. The Science of the Total Environment 81/82, 187-194.

Harvey, H.J., Fallon, R.D., Patton, J.S., 1986. The effect of organic matter and oxygen on the degradation of bacterial membrane lipids in marine sediments. Geochimica et Cosmochimica Acta 50, 795-804.

Hatcher, P.G., Berger, I.A., Mattingly, M.A., 1980. Structural characteristics of fulvic acids from continential shelf sediments. Nature 285, 560-562.

Hatcher, P.G., Simoneit, B.R.T., Mackenzie, F.T., Neumann, A.C., Thorstenson, D.C., Gerchakov, S.M., 1982. Organic geochemistry and pore water chemistry of sediments from Mangrove Lake, Bermuda. Organic Geochemistry 4, 93-112.

Hatcher, P.G., Breger, I.A., Dennis, L.W., Maciel, G.E., 1983a. Solid-state ${ }^{13} \mathrm{C}$ NMR of sedimentary humic substances: new revelations on their chemical composition. In: Christman, R.F., Gjessing, E. (Eds.), Terrestrial and Aquatic Humic Materials. Arbot Science Publishers, pp. 37-81.

Hatcher, P.G., Spiker, E.C., Szeverenyi, N.M., Maciel, G.E., 1983b. Selective preservation and origin of petroleum-forming aquatic kerogen. Nature 305, 498-501.

Hatcher, P.G., Breger, I.A., Maciel, G.E., Szeverenyi, N.M., 1985. Geochemistry of humin. In: Aiken, G.R., McKnight, D.M., Wershaw, R.L. (Eds.), Humic Substances in Soil and Water. Wiley, New York, pp. 275-302.

Hedges, J.I., 1988. Polymerization of humic substances in natural environment. In: Frimmel, F.H., Christman, R.F. (Eds.), Humic Substances and their Role in the Environment. Wiley \& Sons, New York, pp. 45-58.
Hedges, J.I., Cowie, G.L., 1991. The role of anoxia in organic matter preservation in coastal sediments: relative stability of the major biochemicals under oxic and anoxic depositional conditions. Organic Geochemistry 19, 229-234.

Hedges, J.I., Keil, R.G., 1995. Sedimentary organic matter preservation: an assessment and speculative synthesis. Marine Chemistry 49, 81-115.

Henrichs, S.M., 1992. The early diagenesis of organic matter in marine sediments: progress and perplexity. Marine Chemistry $39,119-149$.

Ikan, R., 1996. The Maillard Reaction; Consequences for the Chemical and Life Science. John Wiley \& Sons, Chichester.

Jakob, G.S., Schaefer, J., Stejskal, E.O., McKay, R.A., 1980. Magic-angle N-15 NMR study of nitrate metabolism of Neurospora crassa. Biochemical Biophysical Research Communications 97, 1176-1182.

Kadouri, A., Derenne, S., Largeau, C., Casadevall, E., Berkaloff, C., 1988. Resistant biopolymer in the outer walls of Botryococcus braunii, B race. Phytochemistry 27, 551557.

Kirk, T.K., 1984. Degradation of lignin (Ed.) In: Gibson, D.T. Microbial Degradation of Organic Compounds. Marcel Dekker, New York.

Knicker, H., Lüdemann, H.-D., 1995. N-15 and C-13 CPMAS and solution NMR studies of N-15 enriched plant material during 600 days of microbial degradation. Organic Geochemistry 23, 329-341.

Knicker, H., Scaroni, A.W., Hatcher, P.G., 1996. ${ }^{13} \mathrm{C}$ and ${ }^{15} \mathrm{~N}$ NMR spectroscopic investigation on the formation of fossil algal residues. Organic Geochemistry 24, 661-669.

Knicker, H., Hatcher, P.G., 1997. Survival of protein in an organic-rich sediment-possible protection by encapsulation in organic matter. Naturwissenschaften 84, 231-234.

Knicker, H., del Rio, J.C., Hatcher, P.G., Minard, R.D., 2001. The identification of protein remnants in insoluble geopolymers using TMAH thermochemilysis/GC-MS. Organic Geochemistry (in press).

Land, L.J., Mackenzie, F.T., Gould, S.J., 1967. Pleistocene history of Bermuda. Geological Society of American Bulletin 78, 993-1006.

Largeau, C., Casadevall, E., Kadouri, A., Metzger, P., 1984. Formation of Botryococcus-derived kerogens. Comparative study of immature Torbanite and of the resistant biopolymer (PRB A) isolated from extant alga Botryococcus braunii. Organic Geochemistry 8, 327-332.

Lee, C., 1992. Controls on organic carbon preservation: the use of stratified water bodies to compare intrinsic rates of decomposition in oxic and anoxic systems. Geochimica et Cosmochimica Acta 56, 3323-3335.

Maillard, L., 1916. Synthese de matières humiques par action des acides amine sur les sucres reducteurers. Ann. Chem. Phys 5, 258-317.

Marshmann, N.A., Marshall, K.C., 1981. Bacterial growth on proteins in the presence of clay minerals. Soil Biology and Biochemistry 13, 127-134.

Mayer, L.M., 1994a. Relationship between mineral surfaces and organic carbon concentrations in soils and sediments. Chemical Geology 114, 347-363.

Mayer, L.M., 1994b. Surface area control of organic carbon accumulation in continental shelf sediments. Geochimica et Cosmochimica Acta 58, 1271-1284. 
McCarthy, M., Pratum, T., Hedges, J., Benner, R., 1997. Chemical composition of dissolved organic nitrogen in the ocean. Nature 390, 150-154.

Nguyen, R., Harvey, H.R., 1998. Protein preservation during early diagenesis in marine waters and sediments. In: Stankiewicz, B.A., van Bergen, P.F. (Eds.), Nitrogen-Containing Macromolecules in the Bio- and Geosphere. ACS Symposium Series 707, ACS, Washington, DC, pp. 88-112.

Nissenbaum, A., Kaplan, I.R., 1972. Chemical and isotopic evidence for the in situ origin of marine humic substances. Limnology and Oceanography 17, 570-582.

Patience, R.L., Baxby, M., Bartle, K.D., Perry, D.L., Rees, A.G.W., Rowland, S.J., 1992. The functionality of organic nitrogen in some recent sediments from the Peru upwelling region. Organic Geochemistry 18, 161-169.

Peersen, O.B., Wu, X., Kustanovich, I., Smith, S.O., 1993. Variable-amplitude cross-polarization MAS NMR. Journal of Magnetic Resonance 104, 334-339.
Rosenfeld, J.K., 1979. Amino acid diagenesis and adsorption in near shore anoxic sediments. Limnology and Oceanography 24, 1014-1021.

Spiker, E.C., Hatcher, P.G., 1984. Carbon isotope fractionation of sapropelic organic matter during early diagenesis. Organic Geochemistry 5, 283-290.

Sun, M.-Y., Lee, C., Aller, R.C., 1993. Anocic and oxic degradation of ${ }^{14} \mathrm{C}$-labeled chloropigments and a ${ }^{14} \mathrm{C}$-labeled diatom in Long Island Sound sediments. Limnology and Oceanography 38, 1438-1451.

Tissot, B.P., Welte, D.H., 1984. Petroleum Formation and Occurrence. Springer-Verlag, Berlin.

Wang, X.-C., Lee, C., 1993. Adsorption and desorption of aliphatic amines, amino acids and acetate by clay minerals and marine sediments. Marine Chemistry 44, 1-23.

Witanowski, M., Stefaniak, L., Webb, G.A. 1993. Nitrogen MNR Spectroscopy. In: Webb, G. (Ed.), Annual Reports on MNR Spectroscopy, 25. Academic Press, London. 